\title{
Reportaż intermedialny Jacka Hugo-Badera i Filipa Springera
}

Edyta Żyrek-Horodyska

TEKSTY DRUGIE 2018, NR 5, S. 372-391

DOI: $10.18318 /$ td.2018.5.22

$\mathbf{Z}$ godnie z ustaleniami Lva Manovicha lata 90. XX wieku przyniosły szereg przemian związanych $\mathrm{z}$ transformacją tradycyjnej, opartej na piśmie kultury analogowej w kulturę cyfrową ${ }^{1}$. Pokłosiem tego zjawiska okazał się dynamiczny rozwój nowych środków masowego komunikowania, które - jak przewidywał już wcześniej Marshall McLuhan - nie przyczyniły się do zniknięcia "starych" mediów, lecz raczej doprowadziły do ich przekształcenia. W efekcie procesu remediacji ${ }^{2}$ pewne cechy starszego medium zostały zachowane, inne z kolei - mniej użyteczne - straciły swą tradycyjną funkcjonalność i znaczenie. Na styku rozmaitych stylów, sztuk i form ukształtował się współczesny reportaż intermedialny, z jednej strony czerpiący obficie z teorii

1 Por. L. Manovich /ęzyk nowych mediów, przeł. P. Cypryański, Wydawnictwa Akademickie i Profesjonalne, Warszawa 2006, s. 61.

2

Pojęcie to, jak podają Jay David Bolter i Richard Grusin, wiąże się z faktem, że media masowe permanentnie oddziałują na siebie. Nowe formy początkowo naśladują te starsze, by kolejno znacząco się od nich odróżnić; J.D. Bolter, R. Grusin Remediation. Understanding the Media, The MIT Press, London 2000, s. 60.
Edyta Żyrek-

-Horodyska - doktor nauk humanistycznych, adiunkt w Instytucie Dziennikarstwa, Mediów i Komunikacji Społecznej UJ. Jej zainteresowania naukowe koncentrują się wokół genologii dziennikarskiej (ze szczególnym uwzględnieniem reportażu literackiego) oraz wokół związków literatury i prasy w pierwszej połowie XIX wieku. Autorka książki Wieszczowie igazeciarze. Europejska publicystyka epoki romantyzmu (WU) 2016). 
tradycyjnych gatunków dziennikarskich, z drugiej zaś starający się w sposób twórczy ją rozszerzać i reinterpretować.

Niniejszy szkic jest próbą opisania i scharakteryzowania przemian, jakim podlegał na przestrzeni ostatnich lat drukowany reportaż literacki, stopniowo ewoluujący od tradycyjnej formy opartej na słowie pisanym w kierunku formy otwartej, intermedialnej, synkretycznej, dążącej do radykalnego rozszerzenia dostępnego rezerwuaru środków wyrazu. W kontekście tych przemian w artykule omówione i przeanalizowane zostaną dwa projekty intermedialne: Boskie światto Jacka Hugo-Badera oraz Miasto Archipelag: Polska mniejszych miast Filipa Springera, ze względu na swój hybrydyczny charakter wymykające się tradycyjnym, skonwencjonalizowanym wzorcom gatunkowym.

Reportaż intermedialny jest kolejną (po reportażu literackim) i - co warto podkreślić - zdecydowanie bardziej radykalną próbą wkroczenia tekstu dziennikarskiego na obszar tradycyjnie zarezerwowany dla form artystycznych. Daje autorowi możliwość twórczego wykorzystania wielu form przekazu, których funkcja zdecydowanie wykracza poza proste informowanie o ludziach i wydarzeniach. Poprzez tworzenie komunikatów opierających się na zróżnicowanych typach mediów dziennikarz zyskuje możliwość wieloaspektowego spojrzenia na badany problem, a jednocześnie wyjścia poza ograniczenia, jakie narzuca mu słowo pisane. Intermedialny reportaż po wtóre - jak wstępnie zakładam - jest formą dostosowaną do zmieniających się oczekiwań odbiorców, z większym zainteresowaniem percypujących komunikaty oddziałujące jednocześnie na kilka zmysłów. Jest odpowiedzią na wzrokocentryzm współczesnej kultury, uprzywilejowującej komunikaty wizualne. Intermedialność współczesnego reportażu często opiera się na aktywnym zaangażowaniu odbiorcy, wychodzącego poza swą tradycyjną rolę i stającego się niejednokrotnie recenzentem, a nierzadko nawet informatorem czy współtwórcą realizowanego i moderowanego przez dziennikarza projektu. Wykorzystanie zróżnicowanych kanałów komunikacji pozwala zatem piszącemu stworzyć wieloaspektową, rozbudowaną narrację, by następnie skutecznie dotrzeć z tak przygotowanym przekazem do zdecydowanie szerszego audytorium.

\section{Wokół badań nad intermedialnością}

Współtworzący leksem „intermedialność" przedrostek inter- konotuje fakt „bycia pomiędzy”, konieczność zniwelowania hermetycznych podziałów między rozmaitymi formami twórczości. Odwołuje się do transgresyjności 
współczesnej kultury. Na nieostrość znaczeniową badanego pojęcia zwracał uwagę uznawany za twórcę terminu Dick Higgins - artysta z kręgu Fluxusu - który jako pierwszy próbował zdefiniować go w swym szkicu Intermedia ${ }^{3}$. W 1965 roku Higgins zauważył, że „większość powstających obecnie najlepszych dzieł łączy w sobie różne środki wyrazu"4. Artysta pozytywnie waloryzował artystyczne projekty czerpiące z technik i narzędzi wykorzystywanych w obrębie kilku dyscyplin, starając się jednocześnie pokazać, że dotychczasowy język opisu sztuki nie zawsze nadąża za przemianami form artystycznych. W swych ustaleniach koncentrował się głównie na nowo powstających artefaktach, odnosząc założenia swojej teorii przede wszystkim do przestrzeni sztuki.

W kolejnych latach badacze, czerpiąc z ustaleń Higginsa, rozwijali jego myśl bądź reinterpretowali jej znaczenie. Analiza sformułowanych dotychczas na gruncie nauk o sztuce definicji wskazuje na wieloznaczność badanego pojęcia i jego semantyczną niestabilność. Zauważyć można, że zaproponowana przez artystę definicja intermedialności uległa w ostatnich latach radykalnemu rozszerzeniu. Gene Youngblood intermedia wiąże z jednoczesnym wykorzystaniem przez twórców rozmaitych mediów w celu wykreowania swego rodzaju „spontanicznego doświadczenia", na wielu poziomach angażującego uwagę widzów. Badacz, kładąc nacisk już nie tylko na samo dzieło, lecz także jego odbiorców, jednocześnie wykracza w swych ustaleniach poza obszar form artystycznych, pokazując ich związki z technologią audiowizualną. Ryszard Kluszczyński przez intermedialność rozumie z kolei „odsyłanie, wchodzenie jednego medium poprzez drugie, wzajemne aktywizowanie i pobudzanie"6. Podziela pogląd Youngblooda, że praktyki intermedialne są w istocie połączeniem artyzmu i technologii. Sytuuje tym samym analizowane pojęcie przede wszystkim w kontekście sztuki.

W świetle przytoczonych wyżej definicji intermedialność z założenia odwołuje się do określonych relacji między mediami, które - oddziałując

3 Por. D. Higgins Intermedia i inne eseje, wyb., oprac. i wstęp P. Rypson, Akademia Ruchu, Warszawa 1985.

4 Tamże, s. 11.

5 Por. G. Youngblood Expanded Cinema, E.P. Dutton \& Co., Inc., New York 1970, s. 348.

6 R. Kluszczyński Film, wideo, multimedia. Sztuka ruchomego obrazu w erze elektronicznej, Rabid, Kraków 2002, s. 76. 
na siebie - konstytuują nowy, zintegrowany przekaz'. Interesująco, jak sądzę, podsumowują to przywołane przez Konrada Chmieleckiego ustalenia Yvonne Spielmann, postrzegającej badane zjawisko w kategorii „fenomenu wymiany pomiędzy rozmaitymi mediami"8. Współcześnie pojęcie intermedialności wykracza poza grunt sztuki czy estetyki, istotnie i twórczo oddziałując na myśl kulturoznawczą, humanistyczną czy medioznawczą. Podważa ono sztuczne i nierzadko umowne granice między poszczególnymi kanałami komunikacji. Magdalena Wasilewska-Chmura celnie puentuje ekspansywny charakter intermedialności, pisząc, że jej dzisiejsza popularność wynika wprost z założeń myśli ponowoczesnej, zgodnie z zasadą, iż „stan bycia między [...] stał się niejako wyznacznikiem współczesności"’. Efektem tego procesu, jak zauważa Krystyna Wilkoszewska, są nowe metafory, za pomocą których badacze starają się opisać współczesną kulturę medialną: „metafora nomadyzmu, internetowej nawigacji, interfejsów rozumu transwersalnego, rhizomatycznej sieci, intertekstualności, intermedialności, interaktywności; metafora «odysei» [...]"10. Pojęcia te zacierającą granicę między twórcą komunikatu a jego odbiorcą.

Obserwowany w ostatnich dekadach rozwój technologiczny pozwala określić współczesne społeczeństwo mianem sieciowego bądź informacyjnego $^{11}$. Wzrastająca rola środków masowego komunikowania oraz ich wyraźnie dostrzegalne oddziaływanie na kulturę przyczyniają się do rozwoju procesu mediatyzacji, prowadzącej do stopniowego uzależniania się sposobu percypowania rzeczywistości od mediów masowych ${ }^{12}$. Zjawiska te pozostały nie

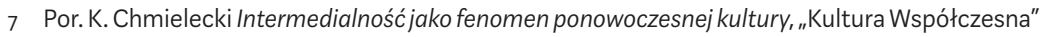
$2007 \mathrm{nr}$ 52, s. 119.

8 Por. tamże.

9 M. Wasilewska-Chmura Przestrzeń intermedialna literatury i muzyki. Muzyka jako model i tworzywo w szwedzkiej poezji późnego modernizmu i neoawangardy, Wydawnictwo Uniwersytetu Jagiellońskiego, Kraków 2011, s. 33.

10 K. Wilkoszewska Prefiksy w roli wyznaczników współczesności, w: Intermedialność w kulturze końca XX wieku, red. A. Gwóźdź, S. Krzemień-Ojak, "Trans Humana”, Białystok 1998, s. 14.

11 Por. A. Hejmej Literatura w społeczeństwie medialnym, "Teksty Drugie” 2014 nr 2, s. 239-241.

12 Zdaniem Stiga Hjarvarda mediatyzacja to "dwustronny proces późnej nowoczesności, w którym media z jednej strony wyłaniają się jako niezależna instytucja, z własną logiką, do której pozostałe instytucje społeczne logiką muszą się dostosować. Z drugiej strony, media stają się integralną częścią innych instytucji takich jak: polityka, praca, rodzina i religia"; cyt. za: M. Molęda-Zdziech Czas celebrytów. Mediatyzacja życia publicznego, Difin, Warszawa 2013, s. 13. 
bez wpływu na twórczość artystyczną oraz sytuujący się na jej pograniczach reportaż literacki, coraz częściej wykraczające poza klasyczną, drukowaną formę. Na widoczne dziś próby poszukiwania przez twórców wciąż nowych form wyrazu zwracał uwagę Andrzej Hejmej, pisząc, że przed literaturą w społeczeństwie medialnym otwiera się wiele możliwości:

istnieje dzisiaj w rozmaitych środowiskach medialnych: od tekstu drukowanego („tekst klasyczny”, forma książki), przez realizacje dźwiękowe (np. radiowe), realizacje sceniczne, instalacje multimedialne, po wirtualną rzeczywistość. ${ }^{13}$

Zaobserwowane przez badacza tendencje dostrzec można już nie tylko na gruncie sztuk pięknych, ale także reportażu literackiego, który z powodzeniem funkcjonuje jako tekst drukowany w prasie, publikowany w formie książkowej, jako fragment słuchowiska radiowego, a nawet - czego doskonałym przykładem jest chociażby Gottland Mariusza Szczygła - jako bezpośrednia inspiracja dla powstania sztuk teatralnych ${ }^{14}$. Przykładem intermedialności reportażu są także coraz popularniejsze fotokasty, będące połączeniem fotoreportażu i reportażu radiowego ${ }^{15}$. Intermedialny charakter wykazują ponadto formy będące efektem fuzji Internetu, sztuki i technologii. Mowa tutaj chociażby o zjawiskach takich jak twitteratura, twitteatr czy powieść na Facebooka.

\section{Intermedialność reportażu}

Współczesne definicje radykalnie rozszerzają znaczenie intermedialności, która zdecydowanie wykracza już poza obszar praktyk artystycznych. Pojęcie to aplikowane bywa także do przemian obserwowanych na gruncie dziennikarstwa, swe komunikaty konstruującego dziś za pomocą nie tylko słowa pisanego, ale i dźwięku czy obrazu. Fenomen ten już w latach 90. dostrzegli badacze niemieccy, by przywołać analizy Jürgena E. Müllera

13 A. Hejmej Literatura w społeczeństwie..., s. 242.

14 Inspiracją dla powstania sztuki teatralnej stała się także biografia Wojciecha Jagielskiego. Przedstawienie 53 wojny, opierające się na książce Grażyny Jagielskiej Miłość z kamienia. Życie z korespondentem wojennym, zrealizował Teatr Ludowy w Krakowie.

15 Por. A. Maćkowiak Fotokast - między kreacjq a manipulacjq̨, "Media, Kultura, Teologia” 2014 S. 41-51. 
uznającego intermedialność za jeden z podstawowych elementów nauki o mediach i współczesnej kultury. Zdaniem badacza w dobie rewolucji medialnej dziedzina ta badania nad telewizją i filmem powinna traktować jako istotny obszar swych zainteresowann ${ }^{16}$.

Zjawisko intermedialności reportażu stawia pod znakiem zapytania dotychczasowe próby typologizowania gatunków dziennikarskich. Jego rozwój jest w pewnym stopniu potwierdzeniem tezy o „zagładzie klasycznych gatunków" (a raczej teorii próbującej je opisać), sformułowanej swego czasu przez Stanisława Balbusa ${ }^{17}$. Przemiany te zapowiadał już Ryszard Kapuściński na kartach Lapidariów, zauważając, że ustalenia teoretyków nie nadążają za niezwykle dynamicznymi przemianami reportażu. Niesłusznie - zdaniem autora Cesarza - gatunki dziennikarskie , ,traktuje się statycznie, jako formy niezmienne. Tymczasem gatunki przechodzą ewolucję, zmieniają się"18. Interesującą odpowiedzią na kryzys tradycyjnych form gatunkowych wydać się może propozycja Edwarda Balcerzana, sugerującego wprowadzenie w miejsce dotychczasowych typologizacji ideę gatunków multimedialnych ${ }^{19}$. Co istotne, jako przykład potwierdzający słuszność postawionej hipotezy, badacz przywołuje m.in. twórczość reportażową, eseistyczną i felietonową, których poetyka oddziałuje nie tyko na formy prasowe, ale zdecydowanie poza nie wykracza, uwidaczniając się również w innych przekazach kulturowych:

owe jakości dają o sobie znać we wszelkich stanach i procesach semiosfery, pojawiają się w mowie pisanej i ustnej, w obrazie i dźwięku, a ich fundamentalne właściwości można rozpoznać niezależnie od przyjętej nomenklatury genologicznej. ${ }^{20}$

Mówienie o intencji reporterskiej pozwala zatem połączyć ze sobą różne formy komunikatów medialnych, bez względu na system znaków, którym się posługują.

Por. J.E. Müller Intermedialität. Formen moderner kultureller Kommunikation, Nodus Publikationen, Münster 1996.

17 Por. S. Balbus Zagłada gatunków, w: Polska genologia literacka, red. D. Ostaszewska, R. Cudak, Wydawnictwo Naukowe PWN, Warszawa 2007.

R. Kapuściński Lapidaria, Czytelnik, Warszawa 1997, s.360.

Por. E. Balcerzan Wstronę genologii multimedialnej, „Teksty Drugie” 1999 nr 6, s. 7-24. 
Intermedialność reportażu wiąże się z szeroko dyskutowanym dziś zagadnieniem konwergencji, rozumianej jako możliwość rozpowszechniania medialnych komunikatów przy użyciu zróżnicowanych nośników treści. Jest ona próbą przeniesienia punktu ciężkości w naukowej refleksji z poddawanego krytyce gatunku właśnie na medium. Jak twierdzi Henry Jenkins,

konwergencję mediów musimy rozumieć jako przepływ treści pomiędzy różnymi platformami medialnymi, współpracę różnych przemysłów medialnych oraz migracyjne zachowania odbiorców mediów, którzy dotrą niemal wszędzie, poszukując takiej rozrywki, na jaką mają ochotę. ${ }^{21}$

Wykorzystywanie przez reporterów rozmaitych form ekspresji (słownej, audialnej czy wizualnej) prowadzi do tworzenia przekazów synkretycznych, które - ze względu na postępujący kryzys prasy drukowanej - stać się mogą interesującą alternatywą dla tradycyjnego, opartego na słowie dziennikarstwa.

Pozostaje jeszcze zapytać, czy rozwój form intermedialnych na gruncie prasy należy wyłącznie rozumieć jako formę Łotmanowskiego formalnego eksperymentu, swoistego „udziwnienia” i uatrakcyjnienia przekazu, czy też raczej jako zabieg funkcjonalnie uzasadniony. Znamienne, że jeszcze kilkanaście lat temu Kapuściński, który prócz pisania tekstów reportażowych z swych podróży przywoził także zdjęcia, konsekwentnie unikał ich włączania w tok konstruowanej narracji. Dzisiejszy stosunek reporterów prasowych do obrazu wydaje się zgoła odmienny, czego dowodem są chociażby prace Filipa Springera, Wojciecha Tochmana czy Witolda Szabłowskiego ${ }^{22}$. W świetle ustaleń Jenkinsa kształt komunikatów medialnych uwarunkowany jest m.in. zmieniającymi się oczekiwaniami odbiorców, którzy posługują się często zróżnicowanymi narzędziami, by dotrzeć do interesujących ich informacji. Intermedialność na gruncie mediów masowych nie jest wyłącznie rodzajem formalistycznego "chwytu” i ludycznej gry z odbiorcą, ale zabiegiem uzasadnionym ewolucją form masowego komunikowania. Pozwala bowiem na szybsze, bardziej efektowne przekazanie informacji za pomocą wielu kanałów komunikowania.

H. Jenkins Kultura konwergencji. Zderzenie starych i nowych mediów, przeł. M. Bernatowicz, M. Filiciak, Wydawnictwo Akademickie i Profesjonalne, Warszawa 2007, s. 9. portaże jak Eli, Eli Tochmana, Miedzianka Springera czy Sprawiedliwi zdrajcy. Sąsiedzi z Wołynia Szabłowskiego. 
Problematyce intermedialności w pracy reportera wiele miejsca poświęcił Zbigniew Bauer, który w swym szkicu interesująco zestawił reportaż drukowany z modelami narracji właściwymi dla mediów audiowizualnych ${ }^{23}$. Badacz stał na stanowisku, że intermedialność nie jest cechą przynależną wyłącznie kulturze ponowoczesnej, choć rzeczywiście dziś te tendencje wydają się najbardziej zauważalne. Cechę intermedialności nosiły już bowiem - zdaniem Bauera - średniowieczne manuskrypty, których autorzy w trakcie konstruowania przekazu wykorzystywali dwie techniki oraz dwa odmienne tworzywa ${ }^{24}$. Równie istotnym głosem w dyskusji nad analizowanym tu zagadnieniem wydaje się szkic Susan Jacobson, poświęcony dynamicznemu rozwojowi reportażu cyfrowego w Stanach Zjednoczonych. Formy te - jak podkreśla badaczka, analizując przekazy „New York Times'a”, charakteryzują się nie tylko hybrydycznością wynikającą z jednoczesnego wykorzystania kilku kanałów komunikowania, lecz także w wielu przypadkach włączaniem odbiorcy w proces konstruowania dziennikarskiej narracji ${ }^{25}$.

Oprócz ogólniejszych opracowań poświęconych intermedialności reportażu publikowane są prace traktujące o poszczególnych tekstach bądź autorach, otwierających się na wyzwania wynikające z procesu konwergencji mediów. W literaturze przedmiotu dominują głównie pozycje poświęcone najnowszemu reportażowi literackiemu. Katarzyna Frukacz, omawiając Dzienniki kotymskie Hugo-Badera, klasyfikuje je jako „reportaż skonwergowany"26, stawiając pytanie o to, w jak dużym zakresie na twórczość wspomnianego autora wpłynął fakt zespolenia ze sobą stylów i języków charakterystycznych dla rozmaitych platform medialnych. Paulina Buczek, analizując Boskie światto, stawia tezę o oddziaływaniu nowych mediów na rozwój literatury faktu ${ }^{27}$. Badaczka skupia się przede wszystkim na projekcie internetowym, akcentując jednokierunkowy tor oddziaływań, których wektor skierowany

23 Z. Bauer Problem intermedialności reportażu międzywojennego, w: Reportaż w dwudziestoleciu międzywojennym, red. K. Stępnik, M. Piechota, Wydawnictwo Uniwersytetu Marii Curie-Skłodowskiej, Lublin 2004, s. 71-85.

Por. tamże.

Por. S. Jacobson Emerging Models of Multimedia Journalism. A Content Analysis of Multimedia Packages Publisked on nytimes.com, "Atlantic Journal of Communication” 2010 No. 18, s. 63-78.

Por. K. Frukacz Reportaż "skonwergowany”. "Dzienniki kołymskie” I. Hugo-Badera jako hybryda medialna " Postscriptum Polonistyczne" $2014 \mathrm{nr}$ 2, s. 139-153.

Por. P. Buczek Wpływ nowych mediów na ewolucję literatury faktu: analiza reportażu multimedialnego Jacka Hugo-Badera "Boskie Światło", "Civitas et Lex" 2015 nr 3, s. 7-16. 
jest od nowych mediów do mediów tradycyjnych. Tymczasem wydaje się, że zależności między tekstem publikowanym w sieci a drukowanym w formie tradycyjnej mają charakter dwutorowy. Obie formy na wielu płaszczyznach pozostają ze sobą skorelowane.

Pisząc o intermedialności reportażu, Natalia Wrzeszcz spogląda na to zagadnienie z perspektywy marketingowej. Omawiając twórczość polskich dziennikarek: Martyny Wojciechowskiej i Beaty Pawlikowskiej, tworzone przez nie reportaże klasyfikuje jako „opowiadania transmedialne”, mające przede wszystkim konkretną wartość marketingową ${ }^{\mathbf{2 8}}$. Jak pisze badaczka,

ten przepływ treści niesie ze sobą zwiększony dostęp do grona odbiorców, którzy posługują się różnymi źródłami, żeby dotrzeć do pożądanych informacji, daje możliwość olbrzymich zysków finansowych zarówno twórcom, jak i sponsorom, bez których ciężko wyobrazić sobie ekspedycje podróżnicze. ${ }^{29}$

Tak postrzegana intermedialność służy przede wszystkim zaktywizowaniu odbiorcy, który - dążąc do poznania całej historii - sięga nie tylko po tekst drukowany, lecz chętnie odwiedza też autorskie strony dziennikarza, śledzi jego wypowiedzi w mediach społecznościowych, przegląda prowadzony przez niego blog. Postrzega dziennikarza jako markę. Zauważalna jest dziś wyraźnie tendencja do multiplikowania przekazów, fragmentaryzowania ich oraz przekazywania za pośrednictwem rozmaitych medialnych platform. W efekcie tego procesu powstają intermedialne formy sylwiczne ${ }^{30}$, migawkowe, łączące w sobie rozmaite typy przekazów.

\section{Boskie światło Jacka Hugo-Badera}

W 2013 roku na stronie internetowej Interaktywna.Wyborcza.pl, należącej do koncernu Agora SA, opublikowano intermedialny reportaż Hugo-Badera Boskie światło. Katarzyna Jaklewicz odpowiedzialna w "Gazecie Wyborczej” za rozwój cyfrowy tak przedstawiła główną ideę nowatorskiego projektu:

28 Por. N. Wrzeszcz Blondynki na krańcu świata. Kobieca opowieść o Czarnym Lq̨dzie, „Annales Universitatis Paedagogicae Cracoviensis" 2013 nr 135, S. 203-214.

29 Tamże, s. 207.

30 Na temat koncepcji sylwiczności por. R. Nycz Sylwy współczesne. Problem konstrukcji tekstu, Ossolineum, Wrocław 1984. 
Interaktywny reportaż przygotowaliśmy jako pierwsza z polskich redakcji. Połączyliśmy tekst Jacka Hugo-Badera oraz jego zdjęcia i materiały wideo, tworząc z nich nową cyfrową formę dziennikarską i nawiązując do nowatorskich reportaży przygotowywanych już wcześniej przez zespoły „New York Timesa” i „Guardiana”."

Internetowy projekt przygotowany przez dziennikarza poprzedzał i zapowiadał opublikowaną w 2014 roku książkę Dtugifilm o mitości. Powrót na Broad Peak, której głównym tematem uczynił reporter wyprawę poszukiwawczą zorganizowaną w celu odnalezienia ciał zaginionych polskich alpinistów: Macieja Berbeki i Tomasza Kowalskiego. Nie była to - co należy podkreślić - pierwsza podejmowana przez dziennikarza próba przekroczenia granic między reportażem internetowym a tekstem drukowanym w wersji książkowej. Wcześniej, pracując nad Dziennikami kotymskimi, Hugo-Bader także zdecydował się na ich udostępnienie w sieci pod zmienionym nieznacznie tytułem Dziennik kotymski. Jak zauważa Frukacz, zmiana ta miała swoje praktyczne umotywowanie: „pluralistyczna forma [wykorzystana w książce - przyp. E.Ż.-H.] sugeruje wzbogacenie publikacji o dodatkowe treści, nieuwzględnione w sieciowym pierwowzorze"32.

Podobny zabieg zastosował dziennikarz w swym reportażu poświęconym Broad Peak. Już tytuł książki Długifilm o miłości... pozwala odnieść wrażenie, że jej autor dąży do zniwelowania tradycyjnych ograniczeń gatunkowych. W tym celu w tok budowanej narracji wprowadza urywki scenariusza przygotowywanego przez siebie filmu dokumentalnego. Jego fragmenty odbiorca może zobaczyć na stronie internetowej Boskiego światła, która staje się tym samym rodzajem multimedialnego apendyksu pozwalającego autorowi przełamać ograniczenia drukowanego medium. Nieprzypadkowy zdaje się także wybór tytułu dla internetowej wersji reportażu. Boskie światto to jednocześnie część frazy pojawiającej się w książce („człowieka, który kocha, opromienia Boskie Światło"33), stanowiącej rodzaj łącznika między cyfrową i analogową wersją opowieści.

31 Wyborcza.pl na wzór "NYT" i "Guardiana" wprowadza interaktywny reportaż, "Press" 2013, http://www.press.pl/tresc/33842,wyborcza_pl-na-wzor-nyt-i-guardiana-wprowadzainteraktywny-reportaz (10.07.2017).

33 J. Hugo-Bader Długi film o miłości. Powrót na Broad Peak, Społeczny Instytut Wydawniczy Znak, Kraków 2014, s. 99. 
Zrealizowany przez Hugo-Badera internetowy reportaż ${ }^{34}$ spełnia główne wymogi stawiane przed dziennikarstwem intermedialnym: jest dziełem hipertekstowym i nielinearnym, pozwalającym użytkownikowi nawigować zgodnie z zamierzonym przez siebie kierunkiem; interaktywnym, a co za tym idzie angażującym bezpośrednio uwagę odbiorcy; hybrydycznym przez wzgląd na łączenie w sobie rozmaitych gatunków dziennikarskich; i w końcu multimedialnym - integrującym tekst, fotografię, dźwięk, film i grafikę. W opublikowanym na stronie internetowej reportażu autor stosuje podział na części, pierwszą z nich - co w sposób istotny nawiązuje do tradycyjnej formy drukowanej - tytułując jako prolog, ostatnią z kolei - jako epilog. Tego rodzaju zabieg może być odczytywany jako rodzaj intertekstualnego nawiązania do tradycyjnych książkowych tekstów reporterskich. W prologu zamieszczona zostaje krótka instrukcja dotycząca technicznych uwarunkowań lektury, jak również adres mailowy redakcji, zachęcającej czytelników do nadsyłania opinii i uwag dotyczących reportażowego projektu. Rozdziały środkowe, zatytułowane kolejno Karawana, Baza i Wycof, korelują z tytułami poszczególnych części wyodrębnionych w książce. Podkreślić należy, że w wersji multimedialnej autor rezygnuje $\mathrm{z}$ tradycyjnych przypisów. Ich rolę w Boskim świetle pełnić mają uzupełniające tekst główny ramki, w których zamieszczone zostają dodatkowe informacje, takie jak kontekst zorganizowania wyprawy, sylwetki najważniejszych postaci czy historia Macieja Berbeki.

Funkcjonalne wykorzystanie przez Hugo-Badera rozmaitych typów mediów pozwala odnieść wrażenie bezpośredniego uczestnictwa w wyprawie poszukiwawczej. Już wejście na stronę internetową uruchamia dźwięk przypominający zawodzenia tragarzy, towarzyszących polskiej ekipie w trakcie podróży. Dołączone do tekstu krótkie, zrealizowane w sposób amatorski filmy nie powielają treści reportażu pisanego, lecz stają się jego istotnym uzupełnieniem. Stosowane zabiegi mają na celu wywołanie wśród odbiorców wrażenia naoczności przedstawianych zjawisk. Na kilkudziesięciosekundowych filmach uczestnicy wyprawy - udzielając odpowiedzi na zadawane zza kadru przez Hugo-Badera pytania - swój wzrok kierują wprost w oko kamery. Dzięki temu zasiadający przed monitorem komputera internauta staje się niejako bezpośrednim odbiorcą poszczególnych wypowiedzi, odnosząc wrażenie, że to właśnie do niego kierowany jest komunikat.

34 J. Hugo-Bader Boskie światło, http://boskieswiatlo.wyborcza.pl/article/boskie-swiatlo.html (10.07.2017). 
Elementem spajającym te rozmaite typy narracji jest postać dziennikarza, pełniącego jednocześnie funkcję reportera, operatora i fotografa. Prowadzona przez Hugo-Badera za pomocą wielu kanałów komunikacji opowieść jest umiejętnym połączeniem perspektywy słuchacza, uczestnika, a momentami także rekonstruktora zdarzeń. W Boskim świetle dziennikarz prezentuje siebie przede wszystkim jako dokumentalistę poszukiwawczej wyprawy, który scalając poszczególne części opowieści, konsekwentnie w trakcie realizowania materiału boryka się z brakiem akceptacji ze strony towarzyszących mu alpinistów. Będąc częścią ekipy, jednocześnie przez jej członków wciąż jest postrzegany jako obcy. Na Broad Peak słuszne okazują się zatem jego przewidywania, które kilka lat wcześniej sformułował w rozmowie z Agnieszką Wójcińską, dotyczące samotności reportera ${ }^{35}$. Na stwierdzenie dziennikarki: „zazwyczaj jeździsz sam. Sam robisz zdjęcia do tekstów”, Hugo-Bader odpowiedział wówczas: „Tak. A wiesz dlaczego? Żeby nie podróżować z nikim. Bo ja w sumie nienawidzę towarzystwa"36.

Książkowa wersja opowieści o wyprawie poszukiwawczej przynosi rozwinięcie uwag i obserwacji zanotowanych na stronie internetowej. W wersji cyfrowej - co warto podkreślić - Hugo-Bader całkowicie rezygnuje z przedstawienia szerokich kontekstów związanych z historią polskiego himalaizmu, a także pomija kluczowe dla Dtugiego filmu... autotematyczne komentarze, dotyczące szeregu trudności, z jakimi borykał się już od momentu, gdy rozpoczął pracę nad gromadzeniem materiału. Zamieszczony na stronie internetowej tekst pełni funkcję streszczenia głównego wątku książki i w znacznej mierze składa się z przytaczanych w mowie niezależnej wypowiedzi uczestników wyprawy. Czytelnik zainteresowany bardziej szczegółowymi kontekstami wyprawy odsyłany jest do Dtugiego filmu... W takim ujęciu Boskie światto, jako dzieło autonomiczne i skończone, jest zatem jednocześnie formą zapowiedzi i promocji przygotowanego reportażu drukowanego. Multimedialny przekaz, choć z pewnością zdecydowanie bardziej atrakcyjny dla współczesnego odbiorcy, w przypadku reportażu Hugo-Badera pozostaje silnie związany $\mathrm{z}$ drukowaną wersją opowieści. Spełnia przy tym założenia kultury 2.0, stymulując odbiorcę do realnego współtworzenia komunikatu i dzielenia się uwagami na jego temat.

35 A. Wójcińska Reporterzy bez fikcji. Rozmowy z polskimi reporterami, Czarne, Wołowiec 2011, s. 232. 
Intermedialność reportażu Hugo-Badera nie łączy się jedynie z wersją cyfrową projektu, lecz dostrzegalna jest także na kartach opublikowanej w 2014 roku książki. Obszerną relację z wyprawy dokumentuje Hugo-Bader zarówno za pomocą słowa, jak i obrazu, zamieszczając na kartach Dtugiego filmu... liczne fotografie własnego autorstwa. Choć w wersji książkowej dziennikarz kładzie nacisk na stworzenie spójnej, uporządkowanej narracji, nie przeszkadza mu to w rozszerzeniu głównego wątku o liczne rozdziały poświęcone genezie i rozwojowi polskiego himalaizmu. Dzięki temu wersja książkowa sytuuje tragiczne wydarzenia z 2013 roku w zdecydowanie szerszym kontekście sukcesów i porażek, jakie zapisały się na kartach historii wypraw wysokogórskich.

Synkretyczny wymiar Dtugiego filmu... ujawnia się przede wszystkim we włączaniu w tok reportażowej opowieści innych form i gatunków. Książkę otwiera przedrukowany w całości list, jaki Hugo-Bader przesłał do Jacka Berbeki, prosząc go o możliwość wzięcia udziału w wyprawie ${ }^{37}$. W książce znalazło się ponadto miejsce na obszerne przytoczenie głosu sieciowych komentatorów, których wypowiedzi publikowane na internetowym forum zostały zacytowane przez dziennikarza rezygnującego w tym miejscu z autorskiego komentarza. Niemniej jednak rozdziały składające się z przedrukowanych opinii internautów tytułuje Hugo-Bader jako „jazgot”, co - jak się zdaje - uznać należy za wybór niezwykle sugestywny ${ }^{38}$. Drukowany reportaż uzupełniają i wzbogacają ponadto fragmenty scenariusza przygotowywanego przez dziennikarza filmu dokumentalnego. Podczas gdy Boskie światto składa się z kilku krótkich dokumentów, wersja książkowa zawiera obszerne stenogramy z nagrań, a także bogate, odautorskie didaskalia, mające na celu jak najwierniejsze odtworzenie realiów wyprawy. W załączonym do tekstu scenariuszu pojawiają się nawiązania do doznań wzrokowych i słuchowych:

Plener. Przed zachodem słońca z panoramą gór w tle. Jacek Jawień wchodzi w kadr i siada na składanym krześle. [...]

- Słychać mnie? - pyta.

- Bardzo dobrze - odpowiada głos zza kamery. - Na oba mikrofony.

Bo drugi jest na kamerze i go nie widać. Zamysł reżysera jest taki, żeby nie ukrywać, że nie jest zawodowcem $[\ldots]^{39}$

Por. J. Hugo-Bader Długi film..., s. 6-7. 
Intermedialność reportażu Hugo-Badera sprowadza się do wykorzystania możliwie szerokiego spektrum kanałów komunikacji. Ze względu na mnogość współistniejących ze sobą form i gatunków zarówno Długi film..., jak i Boskie światto mają charakter synkretyczny. Przyjęta konwencja pozwala reporterowi w sposób zdecydowanie pełniejszy, wieloaspektowy opisać przedstawioną rzeczywistość, a także zestawić ze sobą różne, nierzadko odmienne sposoby jej percypowania. W przypadku reportażu Hugo-Badera relatywnie niewielki nacisk położony został na rolę odbiorców, którzy mogą, co prawda, ocenić i skomentować projekt, jednak nie biorą bezpośredniego udziału w jego powstawaniu.

\section{Miasto Archipelag Filipa Springera}

Intermedialny projekt Springera rozpoczął się w 2015 roku i również - jak w przypadku Hugo-Badera - zainicjowany został nie samą publikacją książkową, lecz serią pomniejszych materiałów zamieszczanych regularnie głównie w Internecie. Zamiarem i ambicją reportera wspieranego przez wydawnictwo Karakter, tygodnik „Polityka”, radiową Trójkę oraz Instytut Reportażu było zorganizowanie dziennikarskiej podróży po Polsce, realizowanej zgodnie z przyjętym przez Springera geograficznym kluczem. Celem wyprawy było odwiedzenie 31 polskich miast, które po przekształceniach administracyjnych z 1999 roku utraciły status województw. Planowana podróż ze względu na niezwykle szeroko nakreślony temat i przyświecającą autorowi chęć uniknięcia prostego skatalogowania odwiedzanych miejsc nie mieściła się w ramach tradycyjnego reportażu podróżniczego. Co więcej, zamiar reportera swym rozmachem wykraczał już od samego początku także poza ramy drukowanego medium:

Opisanie każdego [miasta - przyp. E.Ż.-H.] klasycznym reportażem byłoby wyzwaniem przekraczającym możliwości jednej osoby. Dlatego też realizację tego projektu postanowiliśmy nieco uspołecznić i zrealizować reporterski eksperyment składający się z kilku kanałów narracji..$^{40}$

Projekt oparto na zasadzie multimedialności i interaktywności. Pierwszym jego etapem było wykorzystanie mediów społecznościowych, takich jak

40 F.SpringerFilipSpringerprzedstawia swójprojektmultimedialny „MiastoArchipelag”, „Press" 2015, http://www.press.pl/tresc/40388,filip-springer-przedstawia-swoj-projekt-multimedialny -miasto-archipelag (10.07.2017) 
Facebook, Instagram czy Vimeo, które służyły nie tylko do informowania o postępach w pracy nad przygotowywanym materiałem czy promowania przedsięwziętych przez reportera ambitnych podróżniczych zamiarów. Jak tłumaczył Springer, zabieg ten motywowany był przede wszystkim chęcią dotarcia do osób szczególnie zainteresowanych życiem opisywanych miast, które mogłyby stać się informatorami dla dziennikarza, a jednocześnie bohaterami Miasta...:

chcemy zbudować wokół tematu byłych miast wojewódzkich społeczność - ich mieszkańców, pasjonatów, ludzi, którzy z tych miast wyjechali bądź do nich wrócili. [...] Społeczność skupiona wokół „Miasta Archipelagu” nie będzie tylko biernie obserwować kolejnych etapów przedsięwzięcia. Naszym zamiarem jest angażowanie poprzez Facebooka do wskazywania wątków, tematów, bohaterów czy problemów, które w ramach projektu i budowania reporterskiej narracji powinienem zgłębić. ${ }^{41}$

W trakcie pracy nad Miastem... Springer chętnie korzystał również z mediów tradycyjnych. Pojawienie się książki poprzedzone zostało cyklem reportaży zamieszczanych w tygodniku „Polityka”, jak również radiową audycją emitowaną w Programie Trzecim Polskiego Radia. Zabieg ten pozwolił dotrzeć do szerokiego grona odbiorców i za pomocą rozmaitych form komunikacji przybliżyć problematykę przedstawioną finalnie w opublikowanej w 2016 roku książce.

Istotną rolę w intermedialnym reportażu Springera odegrała także strona internetowa miastoarchipelag.p ${ }^{42}$, która - analogicznie jak Boskie światto - opierała się na fragmentach reportaży autora, wzbogaconych o wykonane przez niego fotografie i krótkie nagrania filmowe. Centralnym punktem strony jest interaktywna mapa, gdzie zaznaczono zarówno biorące udział w projekcie miasta, jak również dni, kiedy odwiedził je dziennikarz. Nawigując między poszczególnymi miastami, czytelnik tworzy niejako własny plan podróży po Polsce mniejszych miast, układając go zgodnie z własnymi oczekiwaniami. Współistnienie wersji cyfrowej z wersją analogową projektu określa Springer mianem dziennikarskiego eksperymentu, który może wskazać jednocześnie dalszą drogę rozwoju reportażu:

41 Tamże. 
Skala projektu i otwarty na odbiorców sposób jego realizacji stwarza okazję do sprawdzenia kilku eksperymentalnych rozwiązań i strategii. Głęboko wierzymy, że poszukiwania adekwatnej do możliwości Internetu formy dla reportażu nadal trwają. „Miasto Archipelag” tylko miejscami będzie opowieścią liniową, w innych obszarach będzie się opierać na mozaikowości, będą tu dominować formy otwarte na aktywność odbiorców. $^{43}$

Jednym z kluczowych etapów prac nad projektem było stworzenie „Magazynu Miasta Archipelagu", zamieszczonego na interaktywnej platformie Flipboard.com. Do współpracy nad publikowanymi tam materiałami zaproszono kilkudziesięciu lokalnych pasjonatów, miejskich aktywistów i dziennikarzy regionalnych, poproszonych o przygotowanie materiałów o problemach i wyzwaniach, z jakimi mierzą się współcześnie mieszkańcy ich małych ojczyzn. Informacje te miały zapełnić widoczną dziś niezwykle wyraźnie lukę w dyskursie ogólnopolskich mediów, w niewielkim tylko stopniu zainteresowanych życiem mieszkańców małych miasteczek. „Magazyn...” stał się także istotnym źródłem informacji dla Springera, który poprzez wykorzystanie tak wielu kanałów komunikacji zyskał możliwość przywrócenia tej problematyki do świadomości zarówno internautów, jak i odbiorców tradycyjnych mediów.

Jak podkreśla Springer, idea stworzenia intermedialnego reportażu zakorzeniona jest jeszcze w myśli Ryszarda Kapuścińskiego. Kilkadziesiąt lat wcześniej w dziennikarską podróż po Polsce autor Cesarza wybrał się, przygotowując wówczas reportaże dla „Polityki”.W Mieście... Springer zatrzymuje się na moment nad reportażem swego poprzednika poświęconym Koninowi, akcentując fakt, że Kapuściński miastu temu poświęcił nie tylko tekst, ale także nieobszerny cykl fotograficzny. Wspominając o Koninie widzianym oczyma Kapuścińskiego, Springer nie konfrontuje własnych zdjęć z fotografiami autorstwa swego poprzednika, lecz decyduje się na wykorzystanie formy literackiej ekfrazy, pozwalającą za pomocą słowa opowiedzieć o oglądanym obrazie:

„Powrót górników ze zmiany” - ledwo ich na tym zdjęciu widać, jest tylko jakiś ceglany budynek i małe figurki ludzi zlewające się prawie z szarością zabudowań. Przez te niedoskonałości Konin wydaje się 
na tych fotografiach jeszcze bardziej niekompletny i umowny, niż był w rzeczywistości. ${ }^{44}$

Springer, w swych wcześniejszych publikacjach zainteresowany głównie problematyką urbanistyczną, architektoniczną oraz obserwowanymi na przestrzeni lat przekształceniami kultury miejskiej, w Mieście... pozostaje wierny swym wcześniejszym dziennikarskim poszukiwaniom. Tym razem wybiera się jednak w podróż zdecydowanie szerzej zakrojoną, bo łączącą 31 pozornie niezwiązane ze sobą punkty na mapie Polski. Co znamienne, swą wyprawę i mającą dokumentować ją historię rozpoczyna nie od człowieka, lecz właśnie od przestrzeni, która staje się dla niego głównym bohaterem opowieści. We wprowadzeniu do książki notuje:

Rozpoczynam podróż, tak jak trzeba, od mapy. Tak jak lubię najbardziej. Moc map tkwi w tym, że nie zaznaczono na nich ludzi. Przestrzeń jest w nich sprowadzona do dwóch wymiarów [...]. Nikt nie zaburza obrazu [...]. Mapa łudzi wolnością, obiecuje swobodę, zwalnia z obowiązków.45

Podkreślić należy, że w trakcie podróży, relacjonowanej jednocześnie za pośrednictwem rozmaitych typów mediów, Springer znacząco modyfikuje swą wstępną hipotezę. Z sieci pozornie niezwiązanych ze sobą narracji, dokumentowanych tekstem, słowem i obrazem, powstaje pozornie tylko fragmentaryczna narracja o Mieście bliżej niedookreślonym, lecz sugestywnie pisanym przez Springera wielką literą:

Tak, im dłużej podróżuję, tym częściej twarze, rozmowy, obrazy, sytuacje odrywają się od przestrzeni. Biorą rozwód z geografią i dryfują w stronę Miasta - sumy wszystkich miast, archipelagu opowieści, zlepku historii. ${ }^{46}$

Podobnie jak poszczególne historie miast łączą się w jedną spójną opowieść, wspólną narrację zdają się tworzyć także rozmaite wykorzystywane przez Springera narzędzia komunikacji. Będąca niejako zwieńczeniem projektu książka łączy w sobie obraz i słowo, uwagi autora i wypowiedzi

F. Springer Miasto Archipelag. Polska mniejszych miast, Karakter, Kraków 2016, s. 189-190.

Tamże, s. 7. 
bohaterów, narrację reportażową i fragmenty artykułów zamieszczanych w innych mediach. Projekt Miasta... urzeczywistnia się za sprawą licznych autorskich fotografii, które stanowią integralną część opowieści. Dostrzegalna jest na nich wyraźna fascynacja Springera detalami architektonicznymi, przesądzającymi o wyjątkowości poszczególnych miejsc usytuowanych na mapie podróży reportera. Springera interesują zarówno aspekty historyczne, jak i współczesna sytuacja demograficzna, kulturalna czy ekonomiczna Polski powiatowej. Uwagę zwraca ponadto mnogość wykorzystywanych form gatunkowych. Autorowi udaje się płynnie łączyć fragmenty reportażu podróżniczego z wywiadami przeprowadzanymi z mieszkańcami odwiedzanych miast. Literacka narracja zestawiana jest z językiem wypowiedzi gazetowych, fragmentami zaczerpniętymi z internetowego forum, a nawet - co nieczęste w publikacjach reportażowych - z wypowiedziami badaczy i myślicieli, których nazwiska pojawiają się w dołączonej do książki obszernej bibliografii. Wielogłosowa opowieść pozwala dziennikarzowi spojrzeć na badane zagadnienie z wielu perspektyw i zderzyć ze sobą kilka odmiennych form przekazu. W ramach intermedialnej struktury dziennikarz scala tekst, dźwięk i słowo, współtworzące obraz archipelagu miasta z uwzględnieniem wszystkich jego tkanek i struktur. Podobnie jak książka Hugo-Badera, Miasto... co prawda daje się czytać z pominięciem kontekstu poprzedzających ją internetowych projektów; odczytanie takie zdaje się jednak w tym przypadku niepełne.

\section{Podsumowanie}

Nakreślone w niniejszym szkicu ustalenia pokazują, że współczesny reportaż literacki jest gatunkiem coraz silniej dążącym do rozsadzenia tradycyjnych ram genologicznych. Dzieje się to już nie tylko na płaszczyźnie poetyki tekstu, stopniowego wkraczania do reportażu elementów fikcjonalnych czy czerpania z formalnych założeń dzieł literackich. W sytuacji, gdy podany został w wątpliwość obiektywizm dziennikarskich narracji, reporterzy szukają nowych, nieklasycznych, nierzadko hybrydycznych i awangardowych form przekazu, które pozwoliłyby spojrzeć na analizowane zagadnienie jednocześnie z kilku perspektyw. Coraz częściej piszący rezygnują z linearności przekazu na rzecz jego fragmentaryczności, otwierającej przed odbiorcami szerokie perspektywy interpretacyjne.

Realizując zasady dzieła otwartego, dziennikarze dążą do przekształcenia biernego dotąd czytelnika w odbiorcę nastawionego na samodzielne generowanie treści, a nawet w sposób bezpośredni zaangażowanego w ich 
tworzenie. Percypowanie komunikatów ma zazwyczaj charakter procesualny i jest rozciągnięte w czasie, dzięki czemu możliwe staje się dłuższe utrzymanie uwagi czytelników. Przygotowywane w ten sposób treści przystosowane są do odbioru na różnego rodzaju nośnikach: zarówno tradycyjnych, jak i elektronicznych. Pozwala to dotrzeć do szerszego grona odbiorców, zaangażowanych jednocześnie we współtworzenie treści, weryfikowanie ich poprawności bądź bezpośrednie dostarczanie informacji reporterom. Intermedialny reportaż podważa zatem tradycyjne granice między reporterem, bohaterem opisywanej przez niego historii a odbiorcą tworzonych komunikatów.

Omówione w niniejszym szkicu projekty łączy przede wszystkim chęć opowiedzenia historii za pomocą kilku kanałów komunikacji. Dzieli natomiast głównie stopień angażowania odbiorcy w rozwój projektu; symboliczny w przypadku Hugo-Badera, kluczowy zaś u Springera. By stworzyć przekaz nowatorski, precyzyjny i możliwie pełny, Springer i Hugo-Bader korzystają z tradycyjnej drukowanej formy reportażowej, wzbogaconej o fotografie i nagrania wideo. Znamienne, że elementem finalnym, wieńczącym niejako przygotowywany w sposób etapowy projekt, dla obu dziennikarzy pozostaje książka, dla której publikowane w sieci materiały pozostają kontekstem i uzupełnieniem. 


\section{Abstract}

\section{Edyta Żyrek-Horodyska}

JAGIELLONIAN UNIVERSITY (CRACOW)

Jacek Hugo-Bader and Filip Springer's Intermedia Reportage

The poetics of literary reportage have undergone certain changes in the recent past. Examining the form's tendency towards intermedia, Żyrek-Horodyska focuses on Filip Springer's Miasto archipelag. Polska mniejszych miast [Archipelago Town: Small-Town Poland] and Jacek Hugo-Bader's Boskie światło [Divine Light]. Both combine traditional journalistic text with new media communication tools, testifying to the hybridization of journalistic genres and their evolution from traditional forms based on the written word towards an open multimedia form that corresponds to the expectations of contemporary media audiences.

\section{Keywords}

intermedia, literary reportage, intermedia reportage, Jacek Hugo-Bader, Filip Springer 